\title{
«Пустые пространства» и их обитатели в городах Дальнего Востока России (на примере города Хабаровска)'
}

\author{
Л.Е. БЛЯХЕР*, А.П. ИВАНОВА**, А.В. КОВАЛЕВСКИЙ***
}

\begin{abstract}
*Леонид Ефимович Бляхер - доктор философских наук, профессор, заведующий кафедрой философии и культурологии, ФГБОУ ВО «Тихоокеанский государственный университет». Адрес: 680035, Хабаровск, ул. Тихоокеанская, д. 136. E-mail: leonid743342@mail.ru

**Алина Павловна Иванова - кандидат архитектурных наук, доцент кафедры дизайна архитектурной среды, ФГБОУ ВО «Тихоокеанский государственный университет». Адрес: 680035, Хабаровск, ул. Тихоокеанская, д. 136. E-mail: iva.nova@mail.ru

***Андрей Владимирович Ковалевский - аспирант кафедры социологии, политологии и регионоведения, ФГБОУ ВО «Тихоокеанский государственный университет». Адрес: 680035, Хабаровск, ул. Тихоокеанская, д. 136. E-mail: fakzy79@gmail.com
\end{abstract}

Цитирование: Бляхер Л.Е., Иванова А.П., Ковалевский А.В. (2021) «Пустые пространства» и их обитатели в городах Дальнего Востока России (на примере города Хабаровска) // Мир России. Т. 30. № 3. С. 150-173. DOI: 10.17323/1811-038X-2021-30-3-150-173

Одной из особенностей российских городов является наличие значительной доли частного сектора и других негородских пространств, включенных в черту города. Как правило, эти пространства рассматриваются и в генпланах развития городов, и в исследованиях ученых как «пустыле пространства», подлежащие трансформации в настоящий город.

Проблема «невидимок» (городских маргиналов), сопутствующая теме «пустых пространств», многократно анализировалась в европейском и американском контекстах, однако в этих случаях она, как правило, была связана либо с бедностью, либо с этнической дискриминацией, что существенным образом сказалось на подходе к этой проблеме в России. Отечественные исследователи зачастую рассматривают эти группь исключительно как социальных аутсайдеров, которых необходимо так или иначе адаптировать $\kappa$ городским условиям. В настоящей статье предлагается иная позиция наблюдателя. Предметом анализа становятся не столько причины попадания в эти пространства или формы адаптации «невидимок» к привычным формам социальной жизни, сколько образ жизни и самосознание жителей негородских анклавов. Эмпирическим материалом вы-

1 Статья опубликована в рамках проекта НИУ ВШЭ по поддержке публикаций авторов российских образовательных и научных организаций «Университетское партнерство». 
ступают включенное наблюдение, две серии неформализованных биографических интервью, проведенных авторами в 2018-2019 и 2020 году в Хабаровске. Дополнительньмм материалом является изучение карт города и данных официальной статистики. В статье показано, что сообщества жителей негородских пространств городов обладают спеичифическим способом производства пространства, активно взаимодействующим с собственногородским пространством именяющим его по своемуобразу и подобию. Описанньй в статье образ жизни для подавляющего большинства респондентов является не столько вынужденной мерой, сколько осознанным выбором. В настоящей статье авторы ставят своей целью выявить и описать особенности образа жизни названных выше групп, обстоятельства, детерминирующие их выбор этого образа жизни.

Ключевые слова: социальное пространство, город, производство пространства, частный сектор, борьба за город, социальные сети, Хабаровск

\section{Введение}

Значительные пространства российских городов ${ }^{2}$, составляющие сегодня до трети их территории (особенно в городах, которые расположены на востоке России [Григоричев 2019]), ускользают от взгляда исследователей-урбанистов и городских властей. Они присутствуют именно как «пустое пространство», которому надлежит превратиться в «нормальное» или в условиях сжатия городов просто исчезнуть. При этом пустым это пространство является не в физическом и даже не в географическом, а в социальном смысле. Как показал в своих работах А. Лефевр, социальное пространство, в отличие от пространства физического, всегда наблюдаемое и считываемое [Lefebvre 1991]. Оно представляет собой «текстуру» - совокупность артефактов, носителей объективированных смыслов, устойчивых модусов поведения [Werlen 1995]. Данный тип социального пространства предполагает определенные виды деятельности и препятствует другим. В этом плане он сближается с содержанием концепта «культурный ландшафт» в трактовке В.Л. Каганского [Каганский 2013]. Однако категория «культурный ландшафт» связана с иной исследовательской программой и во многом с иной дисциплиной. В силу этого мы предпочли остановиться на концепте «социальное пространство». В задаваемой этим концептом теоретической рамке, как показывает А.Ф. Филиппов, развивая идеи А. Лефевра, термины «пустое» и «заполненное» пространство из метафор превращаются во вполне определенные понятия. Если «текстура» не содержит ожидаемых наблюдателем знаков, которые можно распознать, как смыслы данного типа пространства (города), оно и оказывается «пустым», «невидимым» [Филиппов 2009].

Однако эти «маргинальные» пространства, как и любые другие пространства городов, населены, и их население, оставаясь «невидимками», «маргиналами», производит пространство, соответствующее его образу жизни, его деятельности [Lefebvre 1991]. Содержащиеся здесь артефакты наделяются ими социальными смыслами, с которым связаны повторяющиеся конфигурации социальных событий и действий. Проблема состоит в том, что эта деятельность почти никак не оформлена в публичном

2 Частный сектор, пустыри, «брошенные» промышленные зоны и т. д. 
пространстве, не порождает дискурса самопрезентации. В силу этого описание подобного пространства и его обитателей оказывается чаще всего внешним; здесь и возникает «пустое пространство». Эксплицировать характеристики данного социального пространства с точки зрения его обитателей мы и попытаемся в настоящей работе.

В академической среде уже сложились традиции исследования городской маргинальности [Park, Burgess 1925]. В основном ее осмысление встраивается в рамку борьбы с бедностью, сопрягается с проблемой неравенства [Renfrew 2013]; ученые фиксируют связь между маргинальностью и миграцией, роль этничности и государственной политики в формировании маргинальных групп [Wacquant 2016]; исследуется сам процесс стигматизации городских территорий и их населения [Wacquant, Slater, Pereira 2014]. Маргинальность здесь рассматривается как вынужденное состояние, из которого необходимо вырваться своими силами или с чьей-либо помощью. Отечественный контекст (особенно за пределами столиц [Лейбовичи др. 2004] и в городах восточной части страны [Бреславский 2014]) обладает в этом плане существенной спецификой. Наряду с вынужденными жителями маргинальных пространств, численность которых невысока, большая часть «маргиналов» сознательно выбирают эту жизненную стратегию. В рамках «борьбы за город» [Harvey 2006] они активно отстаивают факт своего существования, хотя и не всегда привычными для исследователя способами.

На примере одного из крупных центров на востоке страны - города Хабаровска - мы постараемся дать описание этих негородских пространств и их жителей, выделяя то, что отличает их от привычных горожан, причины выбора негорожанами этого образа жизни, доказать сам факта выбора.

Эмпирическим основанием, с помощью которого мы рассчитываем решить обозначенные выше задачи, выступает полевое исследование, проведенное авторами в 2018-2019 гг. в ходе реализации проекта «Дальневосточные предместья»³. Оно состояло из включенного наблюдения и серии биографических неформализованных интервью с обитателями этих периферийных пространств города. Отбор осуществлялся по принципу «типичный случай» (9 интервью). Предметом исследовательского интереса был прежде всего образ жизни респондентов. Поскольку задачи проекта отличались от тех, которые поставлены в настоящей статье, материал был дополнен сравнительным изучением карт города. На основе анализа базы данных ЕГРЮЛ по частному сектору, данных ГИС-систем и публичной кадастровой карты, данных официальной статистики был оценен масштаб «невидимого» пространства и «невидимых» жителей. Также дополнена коллекция биографических интервью. На первом этапе в качестве респондентов выступали лица без определенного места жительства и люди, входящие в их сообщества, хотя и имеющие собственное жилье. В исследовании 2020 г. респондентами стали жители частного сектора и обитатели городских локаций, расположенных вблизи «пустых пространств». В данном случае гайд предполагал анализ хозяйственной жизни респондентов из социального окружения (6 интервью). Принцип отбора респондента был идентичен первому. Поскольку большая часть материала представляла собой неформализованные интервью (дискурс), то и обработка его проводилась с помощью дискурсивных аналитических техник, которые позволили реконструировать систему устойчивых представлений респондентов и наиболее распространенные социальные и хозяйственные практики.

3 Грант РФФИ. 


\section{Город Хабаровск: исторический экскурс в маргинальные пространства}

О частном секторе, наследии советской урбанизации, писалось неоднократно [Глазычев 1995]. Разрастающиеся города поглощали пригородные села, притягивали к себе отдаленную хору, формально превращая сельских жителей в горожан [Меерович 2005]. При этом, несмотря на изменение занятости, образ жизни, свойственный именно сельской местности, сохранялся. Сами пространства частной усадебной застройки, как и пустыри, в рамках городского планирования представлялись как временные и, соответственно, из процесса осмысления города как единого целого [Линч 1982] они просто выпадали ${ }^{4}$. В городах востока России (в т. ч. в Хабаровске) гораздо более значимыми были иные формы образования частного сектора. Возникновению и развитию Хабаровска не предшествовало и не сопутствовало развитие аграрной периферии: город возник и развивался как военный и административный центр, слабо связанный с хозяйством прилегающей территории.

Трагические для жителей Хабаровска перипетии Гражданской войны в Приамурье привели к резкому сокращению численности населения с 53 тыс. до 20 тыс. чел. [Морозов 1988], но уже к 1928 г. довоенный уровень был превзойден за счет массового притока населения в регион. Город превратился в центр Дальневосточного края и Дальневосточного военного округа, что в свете военной концепции освоения Дальнего Востока, принятой в начале 1930-х гг., было еще более значимо [Ткачева 2013]. В условиях массовой миграции возник острейший дефицит жилья, в качестве которого использовались землянки, «ленинские комнаты» и даже рабочие кабинеты [Кулинич 2006]. Частично проблема решалась за счет строительства бараков, которые до сих пор сохранились в отдельных районах города; другой формой решения проблемы явилась усадебная застройка (частного сектора). Миграция в города из сельской местности не была в нашем случае определяющим фактором.

К середине 1950-х гг. численность населения города достигла 280 тыс. чел. ${ }^{5}$, при этом частный сектор составлял более половины территории города. С 1960-х гг. начался стремительный рост Хабаровска, и за последние 30 советских лет население города увеличилось до 600 тыс. чел. Достаточно долгий период сокращение доли частного сектора шло за счет разрастания городской застройки, но в 1980-е гг. усилилось наступление на частный сектор ${ }^{6}$. И если в предшествующий период происходили снос бараков и усадебных строений и возведение на их месте многоэтажных домов, и это ограничивалось в основном центром города и прилегающими к нему районами, «парадной» частью города или пространствами, примыкающими к крупным предприятиям, то в последнюю декаду советского периода снос частного сектора велся по всему городскому пространству. Появилась регулярная городская застройка в южной части города; несколько позже этот процесс распространился на северную часть города, где был построен

\footnotetext{
4 Этот процесс частично можно отметить и в Хабаровске [Врублевский 2013].

5 Здесь и далее данные приводятся по: Государственный архив Хабаровского края. Хабаровский городской отдел статистики Хабаровского краевого управления статистики Государственного комитета РСФСР по статистике; г. Хабаровск, 1932-2006 гг. - Ф. Р928.

6 Государственный архив Хабаровского края. Департамент архитектуры, строительства и землепользования администрации города Хабаровска. Отчеты инспекции Госархстройнадзора (с 1950-х гг.). Ф. Р1743, оп. 2.
} 
«Северный» микрорайон. Как отмечают респонденты, именно в этот период изменились названия вернакулярных районов: например, район «Серая лошадь» стал называться «Кинотеатр “Хабаровск”». При этом частно-усадебная и барачная застройки не исчезли, но их доля стала несколько скромнее (менее 37\% территории), однако главное заключалось в том, что они перестали определять образ города.

Вплоть до 1960-х гг. значимой оппозицией в городском пространстве для районов частной застройки выступал только центр города, что соответствовало городским границам первого десятилетия XX в., и хабаровчане, проживающие за пределами центра, четко ощущали эту оппозицию. В интервью постоянно встречаются фразы «ездили в город», «добраться до города» и т. д. Впрочем, и городской статус центра города в этот период был не вполне очевиден: практика содержания коров ${ }^{7}$ исчезла только в 1950-е - начале 1960-х гг. в связи со строительством городских бульваров на месте речек Плюснинки и Чердымовки, вокруг которых формировалась «сельскость» центра.

В 1980-е гг. ситуация усугубилась: к противопоставлению «центр - окраины» добавилась оппозиция «городские районы - районы частной застройки». Теперь «пустые», подлежащие освоению с точки зрения генпланов развития города, пространства начали восприниматься как особые пространства, другие по отношению к городу. В них не действовали нормы, принятые «в городе», но реализовались иные хозяйственные практики.

\begin{abstract}
«Если мы по молодости хотели спокойно выпить с друзьями, <..., или в “деревямки” за Руднева (улица, примыкающая к частному сектору - авт.). Туда менты даже не совались. <..> Там можно, если деньги есть, и с водочкой посидеть. И никто не спросит: “Тебе сколько лет?”. < ..> Там все иначе было, чем в городе. <...> Да даже если нет денег, всегда можно сэмом (самогоном - авт.) разжиться, там почти все гнали. Если кореш там есть, то не только сэма, но и помидорчики с огурчиками на закусь дадут. В “деревяшках” у всех свои помидоры, огуриы, картошка. Многие и свинок держали, <..> у кого-то даже коровы были» (мужчина, 58 лет, работник СМИ).
\end{abstract}

Отметим, что респондент подчеркивает как необычное для горожанина не только отсутствие властного контроля, но и сельские занятия жителей частного сектора. Однако такие выделенность, «сельскость» не исключали эти пространства из города. Жители частного сектора учились в тех же школах (по месту жительства), что и жители новых районов, лечились в тех же поликлиниках, ходили в те же кинотеатры и Дома культуры и т. д. Дружеские связи между жителями «домов» и «деревяшек» поддерживались очень активно.

«У нас все родители, почти все, работали на заводе Кирова (предприятие в северной части города - aвт.). Это очень объединяло, особенно в те годы. Тогда же все было от завода: и путевки на отдых, и мероприятия всякие. <...> Мы все были с "Кирова". Мы знали, конечно, что живем в Хабаровске, но ощущалось, что наш район как бы

\footnotetext{
7 Но еще в 1960-х гг. на совещании коммунальных работников города обсуждалась борьба с домашней птицей, которая разоряла цветники и клумбы [Врублевский 2013].
} 
стоял отдельно. Мы даже на демонстраџии 1 мая или 7 ноября ходили не в цеентре, а возле ДК» (женщина, 59 лет, учительница).

Поддерживались между городом и «городской деревней» и хозяйственные связи, и об обмене между этими частями города упоминают все респонденты, причем в условиях тотального дефицита советской эпохи такие связи были достаточно значимы.

«Сегодня вот новая мода пошла - раздельный мусор, раздельное собирание мусора. Так у нас такое было еще в моем детстве. Съедобные остатки, особенно хлеб, собирали в отдельный пакет, потом за ним тетка приходила. А она нам за это молока задешево, сальиа, мяса, и не такого, как в магазине, а нормального, свежего» (мужчина, 58 лет, работник СМИ).

Наступление на частный сектор продолжилось и в постсоветские годы. В центре города, где земля была особенно дорогой, но многие частные строения усадебного типа находились под охраной государства, оно приняло форму поджогов ${ }^{8}$, уничтоживших достаточное количество памятников деревянной архитектуры конца XIX в. В ходе масштабной реконструкции исторического центра города на рубеже XX-XXI вв. большая часть районов частной застройки была ликвидирована, а на их месте возникли новые жилые кварталы, ледовый стадион, развлекательные центры, кафе, деловые центры и т. д. В других районах города процесс протекал более мягко: частные дома сносились, а жители переселялись в новые строения за счет государственных или муниципальных структур.

Сегодня районы частной застройки сохраняются на некотором удалении от центра. В ходе анализа карт и базы данных ЕГРЮЛ было установлено, что эти пространства в Хабаровске составляют сегодня не менее 18\% территории: здесь располагаются (с учетом строений СНТ, переоборудованных для постоянного проживания) 17600 строений, в которых проживают около 60700 чел. (погрешность расчетов составляет 5\%) (рисунок 1$)$.

В 1990-е гг. на месте значительной части промышленных зон образовались заброшенные пространства и пустыри: частично они застраивались, особенно в центре города, но на окраине их застройка еще далека от завершения (рисунок 2), и этих территорий в сознании горожан просто не существует.

«Ну, за Политэном есть госпиталь пограничный. Дома всякие на Ламанше (народное название ул. Бондаря - авт.), гаражи какие-то. А там дальше, аж до “Самбери” (гипермаркет - авт.) считай, нет ничего. Я там и не бываю. Что там делать?» (женщина, 59 лет, учительница).

8 Один за другим горят памятники деревянного зодчества в Хабаровске (2013) // Amurmedia.ru. 5 февраля 2013 // https://amurmedia.ru/news/255316/?from=31 


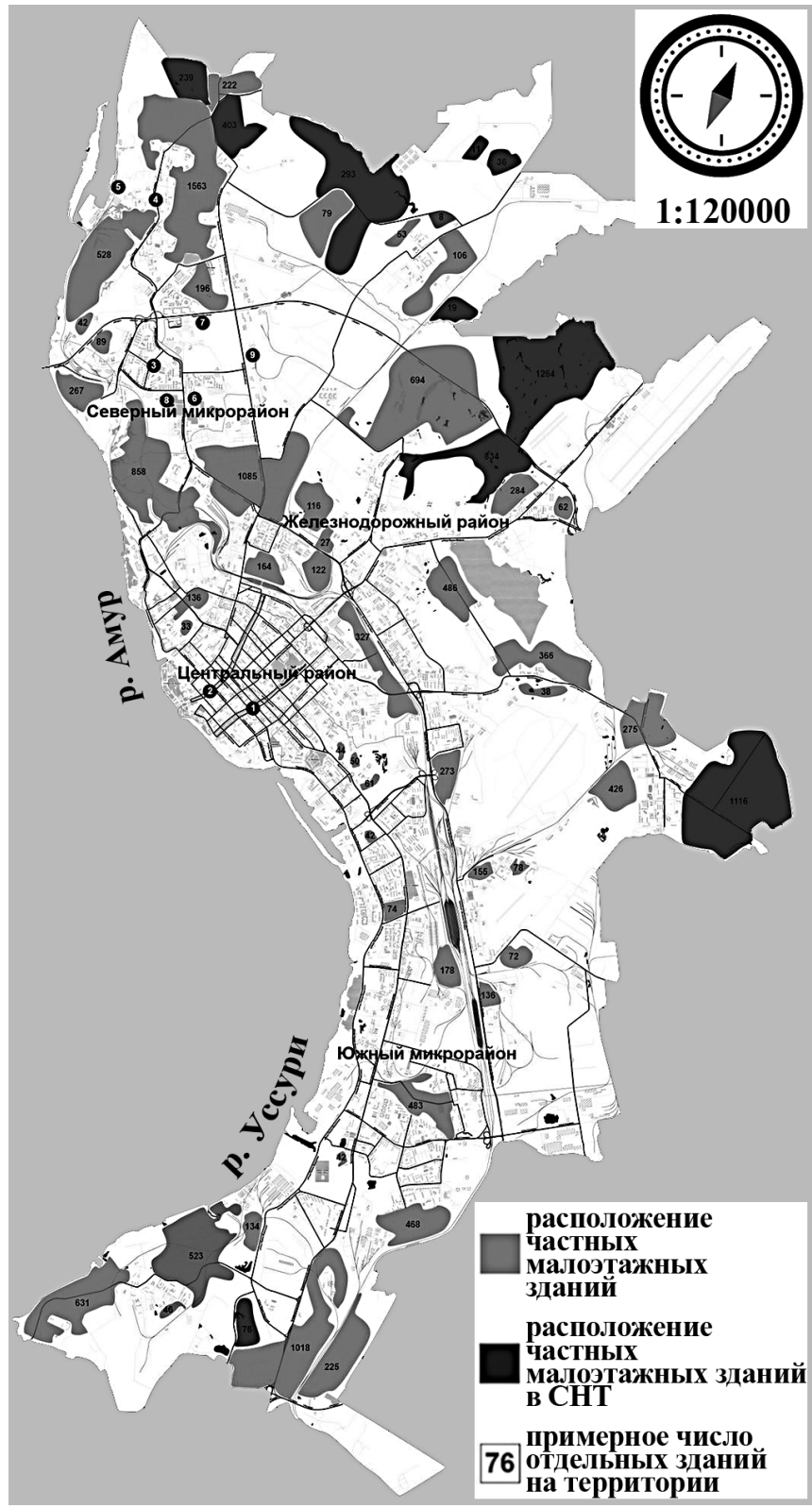

Рисунок 1. Районы частной застройки Хабаровска9

Составлено авторами с помощью сервисов QGIS и OSM по данным из ЕГРЮЛ, приложений Яндекс.Карты, Google Мaps и публичной кадастровой карты.

9 Легенда городских обозначений и названий районов вернакулярных районов: 1. Уссурийский бульвар (бывшая р. Чердымовка); 2. Амурский бульвар (бывшая р. Плюснинка); 3. «Серая лошадь»; 4. Ул. Руднева; 5. Завод Кирова (завод «Остон»); 6. ТОГУ (Политен, Политех и пр.); 7. Гипермаркет «Самбери» (в Северном); 8. Парк «Северный» (стрельбище); 9. Завод «Балтика». 


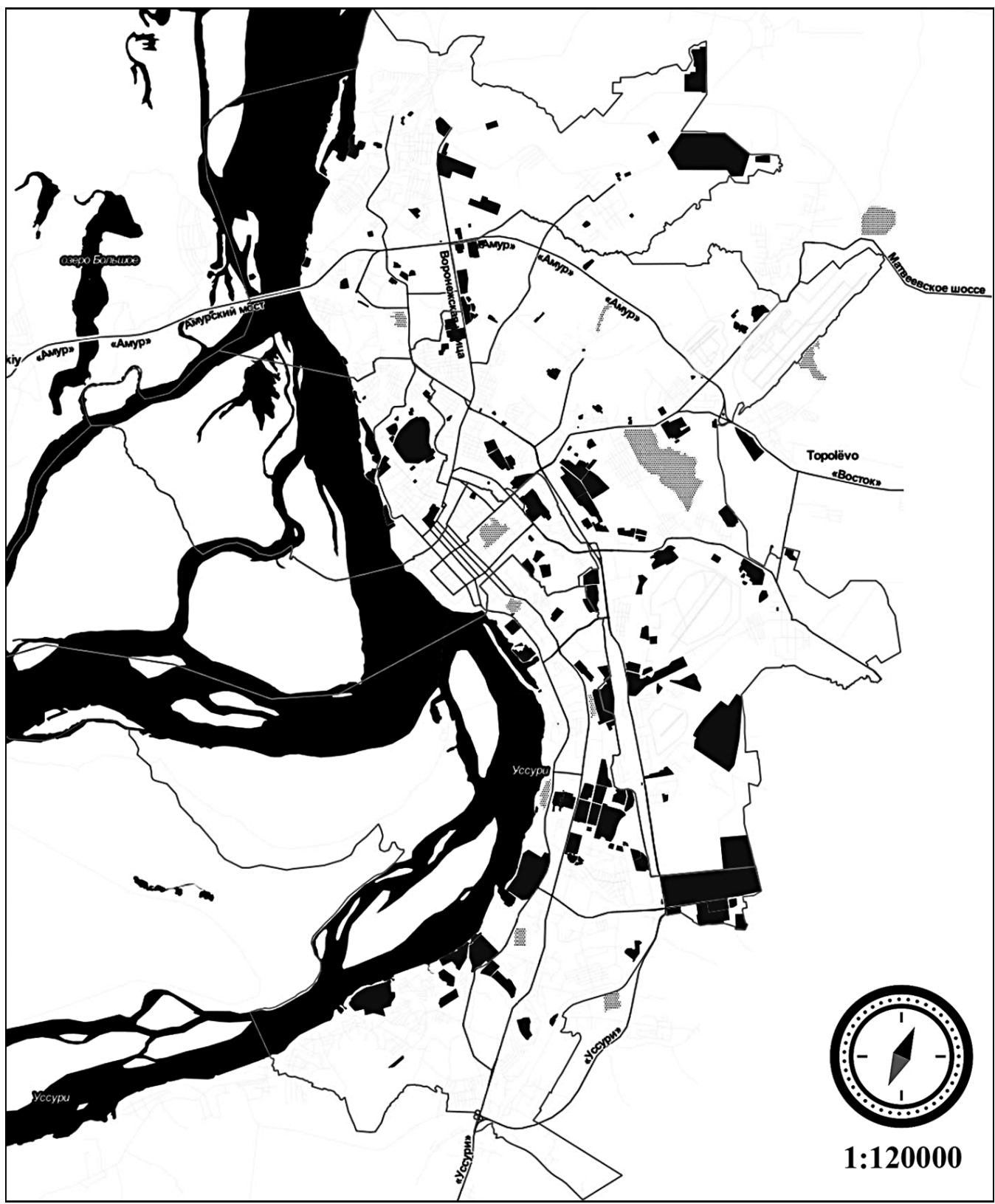

Рисунок 2. Карта размещения промышленных зон в Хабаровске 
Интересно, что к подобным пространствам респонденты относят и гаражи, самовольно установленные жителями в 1990-е гг. и сохранившиеся до сих пор.

«У нас в "Северном" “танхаек” и других бечевников, считай, что уже и не осталось почти. Но у нас все бичи, как мне кажется, в гаражи переселились, там и живут. Я, если иду с электрички, стараюсь никогда угол не срезать через гаражи, даже когда очень тороплюсь. Как говорится, иелее будешь» (женщина, 59 лет, учительница).

Но именно в этих несуществующих пространствах разворачивается хозяйственная деятельность «негорожан». Следует отметить, что значительная часть сельских видов деятельности осуществляется не столько на участках при доме, сколько на «ничьей» земле (пустырях): там высаживается картошка, овощи и даже, по воспоминаниям одного из респондентов, арбузы. Наличие рядом «ничьей» земли отмечается как значимое благо, как, например, и наличие колонки, водопровода.

«Помните, там, где сейчас парк возле церкви, раньше было стрельбище Политэна (местное именование университета - авт.) и Ботанический сад. Это потом там все дорожками заставили, скамейками, беседками, пруд вырыли. А в прежние годы - благодать. <..> Там мы картошку садили, земля там хорошая: картошка была просто объедение, с одного участка на всю зиму запасали. Да, все там садили: и помидоры, и огуриы» (мужчина, 61 год, бывший житель частного сектора).

Сегодня «ничьи» пространства сокращаются, поэтому для исследуемой группы большую ценность представляют оставшиеся «угодья», особенно, если они хоть как-то защищены от вторжения (застройки), и такой защитой в данном случае выступает стигматизация. Как неоднократно отмечалось, подобные негородские районы городов воспринимаются как опасные [Казакова 2017]. В приведенных выше цитатах выстраивается иной облик районов частной застройки, но следует отметить, что подобная идиллия характерна только для «своих трущоб»: чем более отдаленным был район от места проживания респондента, тем более враждебно он воспринимался. Эта ситуация сохраняется и в настоящее время: так, практически во всех интервью, собранных в 2020 г., отмечалось, что районы частной застройки являются опасными; туда неохотно едут таксисты, там живут маргиналы, процветают наркомания и уличное хулиганство. Пространство частной застройки, брошенных промышленных зон, пустырей, гаражей выступает, с одной стороны, опасным, «грязным» [Дуглас 2000], а с другой, эта черта делает его привлекательным для жителей таких пространств, защищает от внешнего вторжения. Общие угрозы, повторяющаяся конфигурация действий и событий, создающаяся на их основе система ценностей формируют население этих «грязных» пространств как отдельное сообщество. Люди, входящие в него, не всегда лично поддерживают коммуникацию «глаза в глаза», но всегда (во всех интервью) знают о наличии соседей. Чтобы понять, почему стигматизация из проблемы становится ресурсом и защитой, попробуем охарактеризовать социальный облик этих жителей. 


\section{Жители «пустых пространств» города Хабаровска}

Как показало наблюдение, проведенное авторами в 2018-2019 гг., социальный состав жителей городской периферии в сравнении с советским периодом значительно изменился. В советские годы это были участники организованных миграционных потоков, прибывшие на строительство новых заводов, но не успевшие обзавестись городским жильем, жители «слободок», захваченные стремительно растущим городом, т. е. в основном «жертвы» незавершенной советской урбанизации. Сегодняшняя картина значительно сложнее.

«Сегодня поселок стал намного меньше. Дома кругом понастроили. Людей туда переселили. <...> Теперь там много других, новых людей. Дома купили, тоже живут: ктото перестраивается, кто-то так живет. Не всегда, но как-то ладим» (мужчина, 69 лет, житель района частной застройки).

Первая «новая» группа - это недавние мигранты из северных территорий региона: во второй половине 1990-х гг. и позднее реализовывалась программа переселения жителей поселков Крайнего Севера, однако денег, выделяемых государством для переселения и на покупку квартиры в Хабаровске или Владивостоке, где можно было найти работу и относительно комфортные условия проживания, не хватало. Многие переезжали в Хабаровский (пригородный) район, но здесь условия жизни оказались хуже, чем в городе, да и работа чаще была в Хабаровске, т. е. приходилось ежедневно тратить деньги и время на дорогу. Выгоднее было покупать частные дома в городе, постепенно их перестраивая.

«Мы в 90-е из Охотска приехали. Я очень не хотела уезжать совсем, хотя Хабаровск люблю, училась здесь. Но там все родное, чистое. Только что делать? Все закрывалось тогда. Родители квартиру в "Северном” купили. Там и другие есть из Охотска. Но больше покупали квартиры в частном секторе, там и дешевле было. И не знаю, как сказать, на дом больще похоже» (женщина, 46 лет, работник университета).

Вторая группа - пострадавшие от постсоветских хозяйственных реформ. После развала предприятий ВПК, сокращения воинских частей (основных работодателей советской эпохи) часть работников просто покинула регион, другая часть смогла адаптироваться к новым условиям, однако часть горожан оказалась выпавшей из социальной структуры. Одной из стратегий адаптации для них стала продажа квартиры, некогда полученной от предприятия с последующей покупкой жилья, минимально пригодного для проживания: как правило, это и был домик в частном секторе на окраине. Поскольку городская квартира была дороже такого строения, у горожанина высвобождались средства, позволявшие существовать какое-то время. Здесь ориентация на подсобные сельскохозяйственные промыслы была намного более активной, хотя выявлялись не только хозяйственные смыслы переезда в частный сектор. 
«Понимаешь, дочка, жизнь какая. Я при СССР уважсаемым человеком был - Герой Труда. <..> А потом эта свистопляска с Горбачевым пошла. Народ посокращали, все закрылось. Вот, оказалось, иди ты, родной, на поклон к спекулянтам. Может быть, они тебя возьмут куда. А я не могу, я-советский человек, не могу я так. Вот и продал квартиру, теперь в доме своем живу. Вот картошку сажу: на выпить и закусить хватает» (мужчина, 71 год, житель частного сектора).

Какую-то часть «новых» жителей составили горожане в первом или «полуторном» поколении, решившие на старости лет перебраться ближе к земле. Иногда это была инициатива детей, решивших отселить пожилых родителей, но не набравших средств на покупку квартиры. Отметим, что и здесь решение о переселении было осознанным.

«А меня дети так вот поселили. Оба образованные: зять Новосибирский университет закончил, кандидат наук; дочка тоже училась, но в Хабаровске. Я во всем себе отказывала, только бы ей образование дать. <..> Они в общаге жили. Я сама их и позвала к себе, у меня двушка была. Есть. А когда внучку родили, тесно стало, вот они мне здесь домик и купили. <... > Теперь вот тут живу» (женщина, 74 года, житель частного сектора).

Появлялись в новых районах и жертвы махинаций с квартирами, и хотя их было немного, однако свою лепту в общую картину изменений они внесли.

В целом, по результатам наблюдения, в частном секторе преобладали пожилые люди, хотя относительно молодые люди тоже встречались, но численно они не доминировали. Среди «молодых» можно выделить две группы: первая - потомственные жители района, которые не смогли или не захотели выбраться из него по каким-то причинам. В качестве причин респонденты называли алкоголизм, тюремное заключение, трудный характер, нежелание жить «среди этих зверей». Отметим типичный (повторяющийся) для группы момент преобладания этического неприятия «новой иерархии» над экономическими мотивами. Справедливость и эгалитарность для большинства респондентов и просто собеседников выступала как сверхценность.

«Я несколько раз пытался, как ты говоришь, на нормальную работу устроиться, но больше на такую лажу не поведусь. Или на деньги кидают: обещают одну зарплату, а платят совсем другое. <..> Или еще хуже: ты для них как слуга. Последний раз я в СТО устроился. Так мне хозяин говорит: “Сгоняй мне за пивом”. Я ему: "Я тебе не слуга”. Он орать. Я ему в лобешник и уволился» (мужчина, 35 лет, житель частного сектора, ремонт машин «на дому»).

Вторая группа относительно молодых людей со средним заработком, мечтающих о собственном доме, появилась, по словам респондентов, в нулевые 
годы. Поскольку средств для строительства коттеджа у них не было, они покупали частные дома, постепенно ремонтируя и модернизируя их. Это наиболее «городские» жители частного сектора, и они в наименьшей степени связаны с местом.

Описывая социальный состав жителей «невидимых» пространств, мы выделили еще три группы, не проживающие в частном секторе, но тесно связанные с ним. Во-первых, это бывшие жители частного сектора, переселенные в строящиеся поблизости многоквартирные дома в рамках программы расселения ветхого жилья. Численно эта группа довольно значительна. Формально не являясь жителями частного сектора, эти люди в большинстве случаев сохраняют связь с прежним социальным окружением и включенность в прежние хозяйственные практики: именно эти жители многоквартирных домов высаживают картофель на газонах во дворах домов. Они наиболее заметны, поскольку оказались в «городском» окружении, не желая принять принципы его существования.

С этой группой достаточно тесно связана вторая группа - люди без определенного места жительства. Классический вариант бомжей, ночующих зимой под мостами и в канализационных люках, описанный в литературе и показанный в кино, в Хабаровске встречается довольно редко. Как отметил один из респондентов, «они просто вымерли». Гораздо более распространенными являются группы, складывающиеся вокруг владельца квартиры, чаще женщины.

«Ну раньще общалась с компанией одной, т. е. с некоторыми людьми из компании. Они ходили зимовать к Людке на Даниловского (улица в северной части города aвт.), их человек 8-10 было. Сейчас не знаю, давно их не видела. У нас тут, понимаешь, свои заботы есть» (женщина, около 30 лет).

Женская роль в рамках подобного разделения труда подразумевает предоставление жилья (особенно в зимний период), иногда и приготовление пищи; мужская роль сводится к функции добытчика: ночлег не явно, но требует оплаты в виде взноса в общий котел. В интервью упоминалась еще одна функция - половая, когда один из постояльцев становится сожителем хозяйки и отцом очередного ребенка, при этом социальная поддержка от государства, выделяемая на мать с ребенком, тоже является ресурсом.

Хозяйственные практики в этих «негородских» районах часто связаны с третьей выделенной нами группой, членов которой можно отнести к предпринимателям. В сферу их интересов входят ремонт автомобилей, квартир, строительство дачных домиков и благоустройство, сбор металлолома, производство и продажа алкоголя и многое другое. Часто, но не обязательно, это бывшие жители частного сектора, хозяева гаражей, будок и т. д. Они - важная часть местного сообщества, его наиболее активная и, что значимо, уважаемая часть, причем именно уважаемая, а не более высокая в иерархии, когда попытки «ставить из себя начальника» неизменно встречают отпор. Это проявляется и в повседневном общении, и в хозяйственных практиках, и даже если реальные отношения подчиненности возникали, они тщательно маскировались. О хозяйственных практиках этих «невидимок» и пойдет речь в следующей главе. 


\section{Что делают \\ и как выживают «невидимки»}

Большая часть лиц, опрошенных в ходе исследования 2018-2019 и 2020 г., не имела легальной занятости, хотя в некоторых случаях она присутствовала, но тем не менее не обеспечивала даже выживания. Легальная занятость, по мнению респондентов, выступает пропуском в легальный мир, где можно использовать льготы и пособия, предоставляемые государством; ту же функцию выполняет и рождение ребенка. Например, легальная работа в кафе является допуском к ресурсу - пищевым отходам, выступающим важным элементом основной деятельности - выращивания поросят на продажу.

Тем не менее, несмотря на отсутствие легальной занятости, «невидимки» занимаются разнообразной и вполне продуктивной деятельностью, которая их кормит, хотя и не ориентирована на получение дохода, скорее, она напоминает «моральную экономику» крестьян [Шанин 1992]. В плане занятости выделяются собирательство, огородничество и реже животноводство, промыслы.

Первая выделенная форма такой активности - собирательство. Во второй половине лета и до первых морозов проводится сбор дикоросов - грибов, ягод, папоротника-орляка, используемого в пищу, некоторых видов лекарственных трав и т. д., которые в основном идут на самообеспечение, но часто предлагаются и на стихийных мини-рынках возле торговых центров или просто во дворах многоквартирных домов.

«Все-таки самое хорошее, что у нас есть, - это природа: река нама, тайга. Мало уже ее осталось, а все равно кормит. Летом и грибочки, и ягоды: брусника, черника, голубика, - тот же папоротник. И себе наберешь, на зиму насушишь, и для людей на продажу. А что? На бутылочку всегда насобираешь» (мужчина, 67 лет, пенсионер, бывший житель частного сектора).

Другим объектом собирательства является содержимое помоек. Причем мусорные баки у обычных панельных домов представляют ограниченный интерес, предпочтение отдается помойкам возле богатых домов или коттеджной застройки. В число «богатых» помоек, по словам респондентов, попали и мусорные баки в университетском городке.

«Ну, понимаешь, тут студенты же, ну и китайцы всякие, они много новых хороших вещей тут выносят, кто кроссовки вот (показывает на ноги свои - $а$ вт.), кто даже по дому штучки всякие, иногда и теплую одежду или еще чего найдет. Ну и бывает даже холодильники, двери деревянные» (женщина, около 30 лет).

И, судя по наблюдениям, число собирателей у одной конкретной помойки не особенно велико. 
«Как мы, ещуе 4-5 семейных приходят постоянно, а так, ну, по мелочи иногда. Постоянно здесь не очень много людей бывает. Они все по квартирам сидят, летом в землянках. Они не часто приходят, в основном такие, как мыз» (мужчина, около 30 лет).

Исключением становятся свалки возле больших магазинов, рынков. В исследовании в этом качестве выступила помойка за продовольственным гипермаркетом «Самбери», куда в связи с жестко контролируемыми сроками на пищевую продукцию ежедневно выставляют ящики с просроченными товарами. С обилием мясной и рыбной продукции, ежедневно выбрасываемой сотрудниками магазина, вероятно, связано отмеченное в интервью сокращение числа домашнего скота в домах частного сектора: ее вытеснил постоянный источник бесплатной пищи.

Не менее значимой формой выживания остается огородничество. В ходе исследования на лесополосе шириной до двух километров и протяженностью более пяти, прерываемой в нескольких местах промышленными зонами, торговыми центрами и коттеджными поселками, были обнаружены огороды с заборами представителей исследуемого сообщества, где выращивались огурцы, помидоры, морковь, капуста и бобовые. Причем на некоторых участках были построены теплицы, собранные из старых оконных рам и обтянутые полиэтиленом. Размеры огородов варьировались в пределах нескольких соток. Их небольшие площади продиктованы отсутствием постоянных источников воды (водопровода или колонок), которое компенсировалось поливом собранной в десятилитровые емкости дождевой водой, принесенные со свалки около гипермаркета «Самбери».

Другой проблемой остается неопределенность статуса. Сложности, возникшие во время исследования при общении с владельцами огородов, которые прятались, завидя незнакомых людей, как позже выяснилось, были связаны с их предположениями относительно статуса интервьюеров, в которых они подозревали сотрудников мэрии, собирающейся отнять у них землю для дальнейшей застройки. По словам респондентов, такое было уже многократно, правда, они нашли выход из положения: стали прикармливать бродячих собак, которые лаяли в случае приближения возможных «агрессоров» (покупателей, застройщиков).

Есть у огородников и другие враги: если расположенные неподалеку дачные поселки обнесены заборами и охраняются (что тоже не гарантирует от набега любителей бесплатной продукции), то огороды в лесополосе охраны лишены, если не считать бродячих псов.

«Да, есть такие, но у них, я думаю, тоже какой-то дом тут есть. Они летом в землянках каких-то прячутся, таскают по мелочи, но несерьезно. $<\ldots>$.. $>$ воруют с огородов, да все там воруют, ипана, с университета вашего уборициь всякие, мы их тут часто видим. Да, там и огороды такие, веревкой обтянутьл, захочешь есть, вряд ли мимо пройдешь» (женщина, около 30 лет).

Сами огородники предпочитают ютиться поблизости от своей земли, по крайней мере, летом; зимой они возвращаются в квартиры или дома. Следует отметить, что не только по словам респондентов, но и по наблюдениям авторов, бездомных 
среди огородников практически нет, однако жилье в данном случае выступает только местом зимовки. Летним жильем становятся шалаши, выстроенные из подручных средств, реже - землянки.

Между огородниками поддерживается достаточно тесная связь. Они ходят в гости, вскладчину нанимают корейцев для рытья водосборных ям или для других трудоемких хозяйственных работ, и, как правило, это очень немолодые люди, у которых отсутствует установка на производство сельскохозяйственной продукции на продажу: в основном речь идет о самообеспечении.

«Я сейчас эти бананы (со свалки у гипермаркета «Самбери»-авт.) в землю закопаю, отличное удобрение. Теперь картошечка будет кормить всю зиму. Я для себя сажу. Продавать? Только если остается. Вот весной останется, тогда и продам. Некоторые и сейчас продают. Аджику делают, которую тоже продают. Я этого дела торговли - не люблю» (мужчина, 83 года, житель частного сектора).

Важно уточнить, что для всех респондентов самым значимым остается именно коммуникация, о которой они упоминали гораздо чаще, нежели о самообеспечении. Значительная часть, привыкнув к активному общению, оказались в старости одинокими, часто запертыми за дверями многоквартирных домов. На огородах они оказываются в привычной среде, возвращаясь к настоящей жизни.

\begin{abstract}
«Я всю жизнь на людях прожила. Работа, семья большая была. А теперь совсем одна осталась. <..> Еще и квартира на восьмом этаже. Раньше выйдешь во двор, хоть с соседкой словом перебросишься, а в нынешних домах никто и знаться ни с кем не хочет, остается только помирать тихонько. Я только здесь на огороде и живу. Люди кругом хорошие и разные. <..> Все лучше, чем в четьрех стенах сидеть, даже болячки проходят, и на зиму припасы заготовлю» (женщина, 68 лет, пенсионер, бывший житель частного сектора).
\end{abstract}

Помимо вышеперечисленного, некоторые из респондентов занимаются сбором и продажей лома черных и цветных металлов, и, как правило, речь идет о не вполне легальных операциях: так, в одном из интервью упоминалось воровство арматуры (с последующей продажей) со строительства здания супермаркета; также практикуются набеги на дачи с последующей продажей на стихийных рынках украденных вещей.

Основная часть промыслов, хотя и располагается «в тени», основана на вполне хозяйственной активности. Выше упоминался наем работников для рытья водосборных ям, что для огородников является скорее исключением, чем правилом, однако для значительной части «невидимок» - это один из наиболее распространенных промыслов. Обслуживание дачных поселков (строительство домиков, бань, ремонт печей, бурение скважин и т. д.) представляет собой хотя и сезонный, но вполне значимый заработок. В предшествующие годы, по словам респондентов, конкуренцию им составляли более дешевые работники из Центральной Азии, 
но в последнее время их число стало совсем незначительным, поскольку этот промысел требует не только специальных навыков, но и наличия инструментов и спецтехники. По словам респондентов, у них существует и определенное разделение труда: «бугор» (бригадир) отвечает за наличие заказчика, его добросовестность в оплате; он же гарантирует качество и сроки строительства. Но, как отмечают респонденты, недобросовестность встречается и с одной, и с другой стороны, а гарантией выступают лишь рекомендации и институт репутации: «Те, кто кидают, в нашем деле долго не задерживаются». Также в инфраструктуру обслуживания дачников входят и выращивание саженцев, возможность предоставления (не всегда посредством покупки) дешевых стройматериалов и т. д. В зимний период ведутся подготовка к сезону и поиск заказчиков; осуществляется ремонт домиков, беседок и заборов. Основной объем работ приходится на весну (начиная с апреля), лето и начало осени. По этой причине вне сезона эти же работники участвуют в других промыслах, ремонтируя квартиры и автомашины. Бригады набираются из жителей-соседей, иногда одноклассников, которых объединяют не только личные связи, но и общее желание «не работать на дядю».

Существует ряд промыслов, связанных с домом, среди которых респонденты называли производство продуктов питания, иногда их перепродажу.

«Ну, честно сказать, когда я в такси работал, меня достало все. “Яндекс” все время химичит. Клиенты - идиоты, вот я их и послал. <..> Теперь вот дома сижу. Баба моя работу работает, а я тоже, только немножко и на себя. Я с детства готовить любил, с мясом возиться. Вот и делаю всю эту фигню (фари и котлеть на продажуaвm.). Ну и самогон творю. Как без него? Продаю, сам знаешь, по своим, а тем, котоpые стучат, не буду. Тебе вот продам» (мужчина, 47 лет, житель частного сектора).

Отмечен в интервью и другой домашний промысел - ремонт машин. В Хабаровске среди автолюбителей бытует устойчивое убеждение, что небольшой ремонт, покраску и т. д. гораздо лучше и дешевле сделать не в автосервисе, а в гаражах ${ }^{10}$. Главным образом речь идет не о легальных гаражных кооперативах, а о «самовольных» гаражах, где можно обнаружить пункт приема лома черных и цветных металлов, автосервисы различной специализации, мебельные, сантехнические и иные мастерские, даже ремонт ПК, работающие без какой-либо регистрации. Предпочтение, которое отдается гаражам, вполне осознанное: стигматизация этого пространства из проблемы становится ресурсом, гарантией безопасности.

В настоящее время теневая деятельность становится все более привлекательной для малого и сверхмалого предпринимательства. На этом уровне институт «уважаемых людей», выполняющих роль третейского судьи и энфорсера, институт репутации вполне позволяют вести дела, минуя государство. В распоряжении авторов имеется неформализованное интервью с представителем этой сферы, дающее полное представление о такого рода деятельности. Респондент - мужчина, 52 года, окончил автодорожный техникум, легального оформления бизнеса нет, что не мешает ему пользоваться известностью у автовладельцев в районе. Некогда

10 О гаражах как о средоточии теневой хозяйственной активности можно прочитать в [Селеев, Павлов 2016]. 
он жил в частном доме, но в настоящее время у него квартира в центре города, помимо трех других, также находящихся у него в собственности; ездит на корейской машине вполне «свежего» года выпуска. Обилие заказов вынудило его прибегнуть к найму работников, но сам по себе найм выглядит как дружеский или соседский обмен услугами. Как отметил респондент, то, что он «свой», позволяет намного меньше тратить на оплату труда работников («Иногда, вообще, посидим за бутылочкой после работы, и все довольны») и легче найти нужного специалиста среди «гаражников» или «на районе». Включение в местные социальные сети становится мощным ресурсом, недоступным для пришлых, но для того, чтобы стать «своим», недостаточно только родиться или некоторое время прожить здесь: необходимо поддерживать принятые стандарты поведения, иначе слишком дорогая машина или одежда автоматически сделают человека «чужаком». Причем чужим становится любой персонаж в случае демонстрации им своего доминирующего положения, и тогда возможен конфликт с непредсказуемыми последствиями.

«У нас тут было один орел объявился, весь такой высокий и гордый. Гараж купил, на джипе приезжал, а народу поляну не накрыл, с уважаемыми людьми не поговорил. Потом стал работников искать, какую-то мебель делать, а его все просто послали по адресу. Тогда он каких-то бичей нанял, возил их на работу и с работы. Ну им быстро объяснили, что им здесь делать нечего, они и слиняли, а потом и орел слинял. У нас не по-людски нельзя» (мужчина, 52 года, владелец «гаражной» автомастерской).

Предприниматель в рамках такой «гаражной» структуры, по сути, выполняет ту же функцию, что и «бугор» при обслуживании дачных поселков, строительстве или ремонте квартир, подобный тип встречается и в собирательстве, и в сельскохозяйственных промыслов; иногда эту функцию берет на себя хозяйка квартиры, где собирается компания бездомных, реализуя собранные дикоросы, украденное с огородов, иногда самостоятельно выращенную продукцию. Наличие такого промысловика, поддерживающего принятые в сообществе стандарты общения, выступает значимым ресурсом для самообеспечения «невидимок». Но и у них, да и у предпринимателей получение дохода не является самоцелью, гораздо важнее сохранение привычного образа жизни, той свободы и взаимоподдержки, которая с ним связана, и в данной ситуации любая внешняя сила - власть, застройщик, контролер или даже врач или соцработник - воспринимается как угроза.

\section{Почему и от кого прячутся «невидимки»}

Одним из неожиданных открытий в ходе наблюдения было то, что уровень жизни исследуемой группы оказался гораздо выше, чем ожидалось. Подавляющее большинство имеет доступ к жилью; у многих есть пенсии или пособия; в некоторых случаях фиксировалась официальная занятость, которая, правда, воспринималась не как возможность обеспечить себя, а как способ дистанцироваться от возможного вторжения государства. О классических бомжах («совсем бомжах») 
упоминалось как о крайне малочисленной, исчезающей группе. Более того, существенная часть респондентов и тех, о ком они рассказывали, без особенных сложностей могли бы изменить свой статус и свой образ жизни на вполне легальный и городской.

«Мне уже сто раз предлагали на работу устроиться, обещали золотые горы. Пару раз даже повелся. <...> Но на любой работе "ты начальник-я дурак". А мне такое счастье зачем? Ищи сам себе рабов, а я дома себе на кусок хлеба с маслом зарабоmаю» (мужчина, 35 лет, автомастерская в частном доме).

Выбор теневого пространства является совершенно осознанным, и предприниматель-промысловик имеет четкое представление о рациональности такого выбора: избегание интереса со стороны многочисленных контролеров и фискальных служб, отсутствие сложной бухгалтерии, удешевление расходов на налоги, оплату труда и т. д. Тем не менее были выявлены и иные группы, далекие от анализа выгод и издержек бизнеса.

\footnotetext{
Интервьюер: «А где ваш муж? Почему он не устроится на работу? Вокруг же много складов, завод "Балтика" стоит, и все в этом роде».

Респондент: «Да туда же в основном только этих набирают, ну, которые с югов понаехали. Им совсем не важно ничего, где спать, где гадить. Получают копейки и горбатятся там ночами. Мой так не пойдет и за такие деньги, он права знает. $<\ldots>$ Он по жизни больше опытный, знает, куда и чего. Не пропадем» (женщина, около 30 лет).
}

В отличие от жителей частного сектора и других негородских территорий советского периода, чей статус воспринимался как временный и вынужденный, современные жители этих пространств и уже вполне городских кварталов, сохраняющих негородской образ жизни, совершают сознательный выбор, извлекая иные выгоды, которые оказываются предельно значимыми для респондентов и сообщества, которое они представляют. В чем же заключаются выгоды отказа от благ современного города?

Город, в далеком прошлом выстроивший механизмы, позволяющие превращать незнакомца, неизвестного в «своего», предсказуемого индивида, сегодня вновь становится местом производства «неизвестных» [Бауман 2008]. Ответ на этот вызов понятен и заключается в создании системы институтов (правил игры и способов принуждения к их выполнению), которые обеспечивали бы предсказуемость поведения «неизвестных», так и не ставших «своими». Но такая система работает только в том случае, когда позволяет лучше организовать легитимный для данного сообщества образ жизни. В этом случае институциональная система ведет к постепенному превращению «неизвестного» и опасного чужого в «своего» через усиление его предсказуемости. Однако в том случае, если легальная система институтов не поддерживает сложившийся образ жизни, возникают альтернативные 
правила игры, которые за пределами легальных институтов формируются на руинах «социалистического города» в «длинные 90-е».

Это особенно актуально для городов востока России, где приток и отток, постоянная смена состава жителей города были особенно значительными: так, в Хабаровске ежегодное обновление состава жителей составляло около 50 тыс. чел. ${ }^{11}$, что для города с населением в 600 тыс. весьма существенно. В этой ситуации, сопряженной с нехваткой жизненно необходимых ресурсов, вызванной удаленностью региона и особенностями советской урбанизации на востоке России, возникает собственный механизм адаптации «чужаков» за счет включения в сети обмена и взаимоподдержки, без которых они просто не смогут выжить. Но в данном случае сеть выступала не целью, а средством сохранения и поддержания образа жизни, описанного выше.

О подобном типе взаимодействия упоминали респонденты старших возрастов по отношению к советскому периоду; о нем говорили и более молодые респонденты в отношении «длинных 90-х» (в регионе - примерно до 2005-2006 гг.).

«У нас так сложсилось, что люди привыкли помогать друг другу, так всегда было. $<$... К Кто-то охотник, кто-то рыбак, кто-то шьет хорошо, а кто-то врач хороший или продавеи в магазине, и не за деньги. Просто помогали кто чем мог. Это нормально. Любой что-то умеет, что-то имеет, вот этим и поделится. <...> Незаконно? Не знаю. Мне кажется, это по-человечески» (мужчина, 67 лет, пенсионер, бывший житель частного сектора).

Сети взаимопомощи оказывались вполне эффективными и в деловом отношении, и в отношении выживания в кризисной ситуации; такой способ организации («по знакомым») сопровождал и достаточно серьезный бизнес [Бляхер (1) 2014]. Но все же особенно важен он был для населения, а не для бизнеса. Наличие плотных сетей взаимопомощи, тянущихся часто из советского и раннего постсоветского прошлого, побуждали наиболее успешных участников оказывать услуги аутсайдерам. Внешне эти услуги выглядели как благотворительный акт, однако лишь отчасти. Такая благотворительность обеспечивала предпринимателю поддержку всей сети, что существенно снижало риски в условиях социальной неопределенности. Личные контакты и межличностное доверие страховали и фундировали неустойчивую систему социальных и правовых институтов, способствовали сохранению сообщества [Bliakher 2013].

«Конечно, я здесь многим помогаю. Нет, я не мать Тереза, даже близко нет. Просто я здесь вырос. Это же люди, с которыми я учился в школе, в технаре. Их родители мне в детстве конфеты давали. Что же: я сегодня их детям помочь не могу, если бабки есть? Конечно, помогу. И сам посмотри: например, захотят меня прищучить. $<$...> Они только подумают о проверке, а меня уже предупредили» (мужчина, 52 года, владелец «гаражной» автомастерской).

11 Государственный архив Хабаровского края. Хабаровский городской отдел статистики Хабаровского краевого управления статистики Государственного комитета РСФСР по статистике; г. Хабаровск, 1932-2006 гг. - Ф. Р928. 
Но «длинные 90-е» закончились, и начиная с 2008 г. в регион хлынул поток государственных денег. Местные виды деятельности частично перестали быть выгодными, частично перешли в распоряжение внешних по отношению к региону игроков, и о новых правилах игры приходилось договариваться в центре; кроме этого, начался отток из региона деловой и политической элиты. В этих условиях инвестирование в территорию со стороны бизнеса лишалось всякого смысла. Если на закате эпохи «региональных баронов» золотопромышленное предприятие «Старательская артель “Амур”» за свой счет провело капитальный ремонт исторических зданий центра города, выстроила в дар городу крупнейший в регионе ледовый стадион, то в «тучные нулевые» таких жестов уже не наблюдалось. Тем значимее была для населения оставшаяся часть бизнеса, включенная в местные сети взаимоподдержки. Формальное повышение заработной платы не всегда и не для всех компенсировало сокращение или исчезновение этих сетей: слишком многое в новых условиях оказывалось платным.

Пространство выживания, включающее в себя дворы, пустыри, «самовольные» огородики и гаражи или вагончики у дачных поселков, используемые в качестве мастерских - все это оказалось под угрозой. На уровне поселений построение вертикали власти приняло форму установления более жестких границ районов и поселений, земельных владений и т. д. [Григоричев 2013]. Навязываемые внешние границы, внешние же правила игры, предполагающие контролируемую структуру городского пространства, оказались смертельно опасными для исследуемого сообщества, которое старается дистанцироваться от инноваций последних десятилетий. Удаленность от центра и наиболее застраиваемых районов города и важнейших магистралей, репутация опасных районов становится не стигмой, а ресурсом, позволяющим избежать излишне пристальное внимание со стороны государства и его контролирующих органов.

\section{Заключение}

При всем различии между людьми, заселяющими негородские пространства городов, на основании анализа эмпирического материала были выделены общие черты, складывающиеся в образ жизни. Во-первых, это отмеченная выше эгалитарность, когда социальный агент не подчиняется, а уважает (старость, мудрость, опыт), когда формат отношений «работник - работодатель» заменяется дружеским или соседским обменом услугами. Во-вторых, работа как особым образом организованное время и место деятельности, отделенное от досуга, в этой реальности отсутствует (даже «будущие владельцы коттеджей» вынуждены так или иначе включаться в эту систему отношений). В результате невидимые официальной статистикой жители стигматизированных пространств оказываются намного более свободными, чем обычные горожане, причем это не фриланс как эффективный способ организации работы в определенных сферах, а образ жизни, где свобода и неиерархичность выступают высшими и безусловными ценностями, а хозяйственные практики вплетены в образ жизни.

Сегодня новые участки частной усадебной застройки, пустыри, лесополосы застраиваются высотками и коттеджными поселками. Кажется, что описанное 
сообщество и производимый им тип пространства в ближайшем будущем канут в небытие, и город, навязываемый извне, удобный для управления, окончательно победит самоорганизующиеся негородские сообщества горожан. Однако эмпирический материал демонстрирует иные перспективы: сообщество сохраняется, несмотря на сокращение привычных конфигураций создаваемого им пространства. Формой борьбы становится наделение собственными смыслами пространства, казалось бы, окончательно захваченного городом. Значительная часть опрошенных респондентов обладает городским жильем (квартирами) или имеет доступ к нему, тем не менее данный тип жилища не приводит к формированию другого образа жизни. Напротив, в огороды превращаются места, отведенные под клумбы и цветники во дворах многоквартирных домов, а сами квартиры - в мастерские, парикмахерские, магазины и даже курятники; обживаются гаражные кооперативы, площадки вокруг торговых центров. В настоящее время все более активной становится хозяйственная жизнь «невидимок» при новых субурбиях и дачных товариществах. Важно, что на этих пространствах хозяйствуют те же люди, которые недавно жили в негородских пространствах города.

Город с его всеобщим знанием и принципами организации не поглощает «негородские» пространства. Городские «невидимки», опираясь на знание того, как «делаются дела», продолжают производить пространство, комфортное для свойственного им образа жизни, и становятся все более «невидимыми», но это будет продолжаться до тех пор, пока остаются лакуны в пространстве городов, цементированном всеобщими принципами градостроительства.

\section{Литература}

Бауман 3. (2008) Город страхов, город надежд // Логос. № 3. С. 24-53.

Бляхер Л.Е. (1) (2014) Государство vs локальные сообщества: как совместить спонтанный порядок и полицейское государство // Пути России: НЛО. С. 68-73.

Бляхер Л.Е. (2) (2014) Искусство неуправляемой жизни. Дальний Восток. М.: Европа.

Бреславский А.С. (2014) Незапланированные пригороды: сельско-городская миграция и рост Улан-Удэ в постсоветский период. Улан-Удэ: Изд-во БНЦ СО РАН.

Врублевский А.В. (2013) Хабаровск шестидесятых: Время надежд. Хабаровск: Юпитер.

Глазычев В.Л. (1995) Слободизация страны Гардарики // Чернышев С. (ред.) Иное. Хрестоматия нового российского самосознания. М.: Аргус. С. 63-68.

Григоричев К.В. (2013) В тени большого города: социальное пространство пригорода. Иркутск: Оттиск.

Григоричев К.В. (2019) «Частный сектор» российских городов: от наследия советской урбанизации к «внутреннему пригороду» // Бреславский А.С. (ред.) «Пригородная революция» в региональном срезе: периферийные городские территории на постсоветском пространстве. Улан-Удэ: Бурятский научный центр СО РАН. С. 22-26.

Дуглас М. (2000) Чистота и опасность: анализ представлений об осквернении и табу. М.: Канон-пресс-ц.

Каганский В.Л. (2013) Как устроена Россия? Портрет культурного ландшафта. М.: Институт Стрелка.

Казакова А.Ю. (2017) Территориальная стигма: содержание и знак оценки // Социальные и гуманитарные знания. Т. 3. № 4(12). С. 357-368.

Кулинич Н.Г. (2006) О социальной мобильности дальневосточных городов (1920-1930-е гг.) // Россия и АТР. № 4(54). С. 24-31. 
Лейбович О.Л., Кабацков А.Н., Шушкова Н.В. (2004) Большой город в постсоветском пространстве // Мир России. Т. 13. № 1. С. 91-105.

Линч К. (1982) Образ города. М.: Стройиздат.

Меерович М.Б. (2005) Квадратные метры, определяющие сознание: государственная жилищная политика в СССР. 1921-1941 гг. Stuttdart: Ibidem-Verlag.

Морозов П.Л. (1988) Хабаровск: История. Современность. Перспективы. Хабаровск: Кн. изд-во.

Селеев С., Павлов А. (2016) Гаражники. М.: Страна Оз.

Ткачева Г.А. (2013) Оборонный потенциал Дальнего Востока СССР в 30-40-е гг. XX в: основные теоретические подходы // Галлямова Л.И. (ред.) Тихоокеанская Россия в межцивилизационном и общероссийском пространстве: прошлое, настоящее, будущее. Владивосток: Дальнаука. С. 415-423.

Филиппов А.Ф. (2009) Пустое и наполненное: трансформация публичного места // Социологическое обозрение. Т. 8. № 3. С. 116-127.

Шанин Т. (ред.) (1992) Великий незнакомец. Крестьяне и фермеры в современном мире. М.: Прогресс-Академия.

Bliakher L. (2013) The Regional Barons // Russian Politics and Law, vol. 51, no 4, pp. 30-39.

Harvey D. (2006) The Right to the City // Divided Cities, Amnesty International Lectures (ed. Scholar R.), Oxford: Oxford University Press, pp. 83-103.

Lefebvre H. (1991) The Production of Space, Malden, MA: Blackwell.

Park R.E., Burgess E.W. (1925) The City (Heritage of Sociology Series), University of Chicago Press; First Edition.

Renfrew D. (2013) "We Are Not Marginals". The Cultural Politics of Lead Poisoning in Montevideo, Uruguay // Latin American Perspectives, issue 189, vol. 40, no 2, pp. 202-217.

Wacquant L. (2016) Revisiting Territories of Relegation: Class, Ethnicity and State in the Making of Advanced Marginality // Urban Studies, vol. 53, no 6, pp. 1077-1088.

Wacquant L., Slater T., Pereira V.B. (2014) Territorial Stigmatization in Action // Environment and Planning A, vol. 46, no 6, pp. 1270-1280.

Werlen B. (1995) Society, Action and Space, London: Routledge.

\title{
"Empty Spaces" and Their Inhabitants in Far Eastern Russian Cities: the Case of Khabarovsk
}

\author{
L. BLIAKHER*, A. IVANOVA**, A. KOVALEVSKI***
}

*Leonid Bliakher - DSc of Philosophy, Professor, Head of the Department of Philosophy and Cultural Studies, Federal State Budgetary Educational Institution of Higher Education "Pacific State University". Address: 136, Tikhookeanskaya St., Khabarovsk, 680035, Russian Federation. E-mail: leonid743342@mail.ru

**Alina Ivanova - PhD in Architecture, Associate Professor of the Department of Design of the Architectural Environment, Federal State Budgetary Educational Institution of Higher Education "Pacific State University". Address: 136, Tikhookeanskaya St., Khabarovsk, 680035, Russian Federation. E-mail: iva.nova@mail.ru

***Andrey Kovalevsky - Postgraduate Student, Department of Sociology, Political Science Regional Studies, Federal State Budgetary Educational Institution of Higher Education "Pacific State University". Address: 136, Tikhookeanskaya St., Khabarovsk, 680035, Russian Federation. E-mail: fakzy79@gmail.com 
Citation: Bliakher L., Ivanova A., Kovalevsky A. (2021) "Empty Spaces" and Their Inhabitants in Far Eastern Russian Cities: the Case of Khabarovsk. Mir Rossii, vol. 30, no 3, pp. 150-173 (in Russian). DOI: 10.17323/1811-038X-2021-30-3-150-173

\section{Abstract}

One of the distinct features of the spatial organization of Russian cities is the significant proportion of single-family residential zones and other non-urban spaces. These spaces are most often viewed as "empty spaces" that need to be transformed into a "real" city. Residents of such spaces are invisible to the observer, and their existence has been repeatedly studied using examples of European and American cities. There they are more often discussed in the context of poverty or ethnic discrimination. This has had a significant impact on how the problem was previously addressed in Russia. These groups were seen as social outsiders who needed to adapt to urban conditions. This article addresses the problem from a different perspective. The subject of analysis is not the reasons for entering these spaces or the forms of adaptation of "invisible people" to the forms of normal social life, but the way of life and self-awareness of residents of such non-urban enclaves. Empirically, the study is based on inclusive observation and two series of informal biographical interviews conducted by the authors in the city of Khabarovsk. Additional material includes city maps and official statistics. The authors show that communities of non-urban spaces of cities have a specific way of producing space. Communities actively interact with the urban space itself, changing it in their own image and likeness. The results show that such behavior for the majority of respondents is not a forced measure, but a conscious choice.

Keywords: social space, city, production of space, "private sector", struggle for the city, social networks, Khabarovsk

\section{References}

Bauman Z. (2008) Gorod strakhov, gorod nadezhd [City of Fears, City of Hope]. Logos, no 3, pp. $24-53$.

Bliakher L. (2013) The Regional Barons. Russian Politics and Law, vol. 51, no 4, pp. 30-39.

Bliakher L.E. (1) (2014) Gosudarstvo vs lokal'nye soobshchestva: kak sovmestit' spontannyj poryadok i policejskoe gosudarstvo [State vs Local Communities: How to Combine Spontaneous Order and Police State]. Puti Rossii: NLO, pp. 68-73.

Bliakher L.E. (2) (2014) Iskusstvo neupravlyaemoj zhizni. Dal'nij Vostok [The Art of Uncontrollable Life. Far East], Moscow: Evropa.

Breslavskij A.S. (2014) Nezaplanirovannye prigorody: sel'sko-gorodskaya migraciya i rost Ulan-Ude v postsovetskij period [Unplanned Suburbs: Rural-Urban Migration and the Growth of Ulan-Ude in the Post-Soviet Period], Ulan-Ude: Izd-vo BNC SO RAN.

Douglas M. (2000) Chistota i opasnost': analiz predstavlenij ob oskvernenii i tabu [Purity and Danger: An Analysis of Concepts of Pollution and Taboo], Moscow: Kanon-press-c.

Filippov A.F. (2009) Pustoe i napolnennoe: transformaciya publichnogo mesta [Empty and Full: Transforming a Public Space]. Russian Sociological Review, vol. 8, no 3, pp. 116-127. 
Glazychev V.L. (1995) Slobodizaciya strany Gardariki [Slobodization of the Country of Gardarika]. Inoe. Khrestomatiya novogo rossijskogo samosoznaniya [Other. Anthology of the New Russian Identity], Moscow: Argus, pp. 63-68.

Grigorichev K.V. (2013) V teni bol'shogo goroda: social'noe prostranstvo prigoroda [In the Shadow of the Big City: The Social Space of the Suburb], Irkutsk: Ottisk.

Grigorichev K.V. (2019) «Chastnyj sektor» rossijskikh gorodov: ot naslediya sovetskoj urbanizacii k «vnutrennemu prigorodu» [The Private Sector of Russian Cities: From the Legacy of Soviet Urbanization to the Inner Suburbs]. «Prigorodnaya revolyuciya» v regional'nom sreze: perife-rijnye gorodskie territorii na postsovetskom prostranstve ["Suburban Revolution" in the Regional Context: Peripheral Urban Territories in the post-Soviet Space] (ed. Breslavskij A.S.), Ulan-Ude: Buryatskij nauchnyj centr SO RAN, pp. 22-26.

Harvey D. (2006) The Right to the City. Divided Cities, Amnesty International Lectures (ed. Scholar R.), Oxford: Oxford University Press, pp. 83-103.

Kaganskiy V.L. (2013) Kak ustroyena Rossiya? Portret kul'turnogo landshafta [How is Russia Arranged? Cultural Landscape Portrait], Moscow: In-stitut Strelka.

Kazakova A.Yu. (2017) Territorial'naya stigma: soderzhanie i znak ocenki [Territorial Stigma: Content and Mark of Assessment]. Social'nye i gumanitarnye znaniya, vol. 3, no 4(12), pp. 357-368.

Kulinich N.G. (2006) O social'noj mobil'nosti dal'nevostochnyh gorodov (1920-1930-e gg.) [Social Mobility of the Far Eastern Cities (1920-1930)]. Russia and the Pacific, no 4(54), pp. 24-31.

Lefebvre H. (1991) The Production of Space, Malden, MA: Blackwell.

Leybovich O.L., Kabatskov A.N., Shushkova N.V. (2004) Bolshoy gorod v postsovetskom prostranstvo [Big City in the Post-Soviet Space]. Mir Rossii, vol. 13, no 1, pp. 91-105.

Lynch K. (1982) Obraz goroda [The Image of the City], Moscow: Strojizdat.

Meerovich M.B. (2005) Kvadratnye metry, opredelyayushchie soznanie: gosudarstvennaya zhi-lishchnaya politika v SSSR. 1921-1941 gg. [Square Meters Defining Consciousness: State Housing Policy in the USSR 1921-1941], Stuttdart: Ibidem-Verlag.

Morozov P.L. (1988) Khabarovsk: Istoriya. Sovremennost'. Perspektivy [Khabarovsk. History. Modernity. Perspectives], Khabarovsk: Kn. izd-vo.

Park R.E., Burgess E.W. (1925) The City (Heritage of Sociology Series), University of Chicago Press; First Edition.

Renfrew D. (2013) "We Are Not Marginals". The Cultural Politics of Lead Poisoning in Montevideo, Uruguay. Latin American Perspectives, issue 189, vol. 40, no 2, pp. 202-217.

Seleev S., Pavlov A. (2016) Garazhniki [Garagenicks], Moscow: Strana Oz.

Shanin T. (1992) Velikij neznakomec. Krest'yane i fermery v sovremennom mire [The Great Unknown. Peasants and Farmers in the Modern World], Moscow: Progress-Akademiya.

Tkacheva G.A. (2013) Oboronnyj potencial Dal'nego Vostoka SSSR v 30-40-e gg: osnovnye teoreticheskie podhody [Defense Potential of the Far East of the USSR in 1930-1940: Basic Theoretical Approaches]. Tikhookeanskaya Rossiya $v$ mezhcivilizacionnom i obshcherossijskom prostranstve: proshloe, nastoyashchee, budushchee [Pacific Russia in the Intercivilizational and All-Russian Space: Past, Present, Future] (ed. Gallyamova L.I.), Vladivostok: Dal'nauka, pp. 415-423.

Vrublevskij A.V. (2013) Khabarovsk shestidesyatykh: Vremya nadezhd [Khabarovsk of the Six-ties: A Time of Hope], Khabarovsk: Yupiter.

Wacquant L. (2016) Revisiting Territories of Relegation: Class, Ethnicity and State in the Making of Advanced Marginality. Urban Studies, vol. 53, no 6, pp. 1077-1088.

Wacquant L., Slater T., Pereira V.B. (2014) Territorial Stigmatization in Action. Environment and Planning $A$, vol. 46, no 6, pp. 1270-1280.

Werlen B. (1995) Society, Action and Space, London: Routledge. 